\title{
THE CONDITION OF SMEs AMID THE COVID-19 PANDEMIC
}

\section{Aliyya Widyadari}

\author{
aliyya11472@gmail.com
}

Indonesia is the largest economy of Southeast Asia. SMEs play a vital role in the Indonesian economy. They are the biggest employer, accounting for nearly $97 \%$ of local jobs. They attract $56 \%$ of business investment in Indonesia. SMEs are important to Indonesia's economic growth, poverty reduction and social inclusion.

In 2020, COVID-19 begins to hit Indonesia and has hit small and medium enterprises (SMEs) hard, through the resulting economic lockdowns and downturns. The Covid-19 pandemic has further eroded people's income and purchasing power. People's savings are increasingly decreasing for consumption needs, especially for those who experienced termination of employment or were laid off, resulting in an increasingly depleted source of household funds. Deflation in July and August 2020 was triggered more by falling prices for several foods, beverage, and transportation groups, indicating the large demand during the Covid-19 pandemic.

Based on the current developing conditions, the government should focus more on controlling the Covid-19 pandemic so that confirmed cases can decrease and give confidence to the public, especially the middle and upper class, to shop again and restore consumption, given that Indonesia's economic growth is still supported by household consumption expenditures. A stimulus for social protection and assistance to businesses can drive consumption growth. The growing consumption and purchasing power of the people will prevent Indonesia from an economic recession, considering that economic recovery with the graph V scenario is still possible, especially since the budget provided by the government is quite large in 2020 or IDR 203.9 trillion for social protection during the handling of Covid-19. However, it should be understood that the economic recovery will not be evenly distributed in all sectors. The government has also prepared various scenarios to save small and ultra-micro business affected by Covid-19, including formulating MSME protection and rescue schemes, ranging from social assistance, tax incentives, relaxation and credit restructuring, to expanding financing. (Tayibnapis et al., 2021) 
Small and medium enterprises are increasingly squeezed by the situation. The decline in spending amid the Covid-19 pandemic is mainly triggered by the weakening of the purchasing power of the lower class and the tendency of the upper-middle segment to withhold spending resulting in further pressure on the income of small and medium enterprises. People tend to only spend on necessities, while unplanned purchases are getting lower. In fact, under normal conditions, unplanned purchases tend to be greater than planned purchases. (Tayibnapis et al., 2021)

However, it should be understood that the economic recovery will not be evenly distributed in all sectors. The government has also prepared various scenarios to save small and ultra-micro business affected by Covid-19, including formulating MSME protection and rescue schemes, ranging from social assistance, tax incentives, relaxation and credit restructuring, to expanding financing. (Tayibnapis et al., 2021)

Various programs for economic recovery have been launched by the government, such as the distribution of Presidential Assistance for micro-businesses, distribution of salary subsidies for formal won Employment (BPJS-Ketenagakerjaan), launching the MSME website, and launching the MSME Digital Market for buying domestic MSME products. All these government programs for economic recovery must be carried out transparently and accountably. (Tayibnapis et al., 2021)

The rapid penetration of the internet in Indonesia has raised hopes for information technology that can empower individuals who have been far from economic and political centers. More than $50 \%$ of Indonesia's population is currently connected to the internet, and various aspects of people's lives are increasingly connected in the digital space for business, social interaction, finance, health care, and education. Ultra-micro and micro-entrepreneurs in underdeveloped villages who have difficulty obtaining capital services from banks can access digital storage services. In fact, access to financial services is the key to driving the internet economy. (Tayibnapis et al., 2021)

The use of digital financial services has the opportunity to drive the internet economy and is expected to support the financing of the productive sector. Ideally, economic achievement through the internet cannot only be seen from the trading platform provider, because the biggest influence is actually felt by the micro, small and medium entrepreneurs themselves. Moreover, the use of the internet can help ultramicro and micro businesses to play 
a bigger role as suppliers in the domestic supply chain so as to reduce the entry of imported goods. (Tayibnapis et al., 2021)

Many parties believe that the MSME recovery program is capable of overcoming poverty and unemployment and encouraging economic growth, both locally and nationally. Local governments that have many MSMEs are trying to provide aid, credit, mentoring, online training, online bazaars, and stimulus funds to help arrange halal certificates and permits for MSME home industry products in an effort to encourage MSMEs to survive in the midst of the Covid-19 pandemic. (Tayibnapis et al., 2021)

Technology-based corporations seem to continue to synergize with ultra-micro, micro, small and medium entrepreneurs in order to increase competitiveness in the market since the concept of digitalization and high creativity is an absolute requirement for market development at this time. Therefore, MSMEs should join the organizers of electronic commerce. (Tayibnapis et al., 2021)

Digital technology is increasingly intertwined with previously unseen advantages. A number of start-ups and e-commerce players, such as Bukalapak, Tokopedia, Kudo, Warung Pintar and Kiosan, are serious about empowering small shops and MSMEs. Various strategies have been carried out by players to stimulate small shops and small businesses, ranging from as a means of channels, online bank payment points for various digital transactions by smart agents, and online to offline businesses. (Tayibnapis et al., 2021)

Every micro, small and medium entrepreneur is equired to be able to personalize their digital tools and make themselves open to the communities they need. Despite the sophisticated information and technology, humans still need to be aware of the purpose of their job or task. Customer Technology users have also taken advantage of services with platforms to reach and connect with each other in order to obtain information and make transactions, both goods and services. Business platforms that are currently developing are no longer reliant on physical assets and natural resources, but on technology-assisted collaborative functions, such as Bukalapak, Blibli, Tokopedia, Shopee, Traveloka, and Lazada, including financial technology start-ups. (Tayibnapis et al., 2021) 